\title{
Meroplankton community structure across oceanographic fronts along the South Brazil Shelf
}

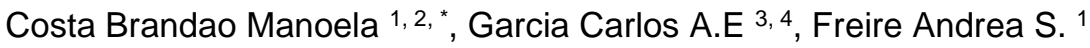

\author{
1 Departamento de Ecologia e Zoologia, Universidade Federal de Santa Catarina, Campus \\ Universitário, 88040-970 Florianópolis, Brazil \\ 2 Institut Français de Recherche pour l'Exploitation de la Mer, Centre de Bretagne, 1625 Route de \\ Sainte-Anne, 29280 Plouzané, France \\ 3 Instituto de Oceanografia, Universidade Federal do Rio Grande, Km 8 Avenida Itália, 96201-900 Rio \\ Grande, Brazil \\ ${ }^{4}$ Programa de Pós-graduação em Oceanografia, Universidade Federal de Santa Catarina, Campus \\ Universitário, 88040-970 Florianópolis, Brazil
}

* Corresponding author : Manoela C. Brandao, email address : manoelacb@yahoo.com.br

\begin{abstract}
:
The influence of oceanographic fronts on the abundance and community composition of invertebrate larvae, mostly of benthic species, along nearly $2000 \mathrm{~km}$ of the southwestern Atlantic shelf $\left(21-34^{\circ} \mathrm{S}\right)$ was investigated. Meroplankton was sampled through vertical hauls at 89 stations, distributed along 14 crossshelf transects, during late spring 2010 and early summer 2011. Salinity and temperature were registered with a CTD/rosette system, which provided seawater for chlorophyll-a and nutrient concentrations estimations. Vertical profiles of temperature, salinity, chlorophyll-a and nutrients were used as proxies of the fronts. In addition, high-resolution thermosalinograph data were used to detect surface frontal features. Meroplankton abundance peaks were found at several fronts intersected by the ship, including upwelling zones, estuarine and plume fronts, a shelf-break front, and two cyclonic eddies. Furthermore, meroplankton abundance was also relatively higher at small-scale thermal and/or saline surface fronts observed along the shelf. Such increases in meroplankton abundance are likely to be ascribed to high nutrient input and primary production. Distinct taxa of invertebrate larvae occurred at different types of fronts, besides the coastal realm, which was virtually dominated by decapod, cirripede and bivalve larvae. Small-scale shelf fronts presented high abundances of decapod and gastropod larvae, for instance, while larvae of polychaetes were the most frequent in the estuarine front of Patos Lagoon section.
\end{abstract}




\section{Highlights}

- The sampling area covers $13^{\circ}$ of latitudinal gradient and up to $400 \mathrm{~km}$ offshore. Large-scale maps of abundance of the main meroplanktonic groups are presented. Physical, chemical and biological variables are analyzed together. Influence of distinct types of fronts on meroplankton abundance is discussed.

Keywords : Frontal zones, Invertebrate larvae, Water mass, Large-scale variability, Southwestern Atlantic 
In neritic pelagic ecosystems, meroplanktonic larvae of benthic invertebrates comprise a large portion of the zooplanktonic community (Shanks et al., 2002; Hidalgo et al., 2014). Despite the limited ability to move, these larvae are capable of controlling their vertical position in the water column (Morgan, 2014). This behavior in conjunction with physical processes will determine whether larvae are exported, retained, or concentrated in specific

51 locations (Cowen et al., 2000).

As a transitional area between the coastal zone and the ocean, continental shelves include water masses of different physical/chemical characteristics and, consequently, a series of frontal zones (Munk et al., 2003). Oceanographic fronts are regions of larger-than-average horizontal gradients of water properties such as temperature, salinity, and density (Joyce, 1983). These confluences of oceanographic processes of contrasting features are usually characterized by high biological productivity (Le Fèvre, 1987; Acha et al., 2015), due to nutrient entrainment, primary/secondary production or aggregation (e.g. Munk et al., 2003; Acha et al., 2015; Hidalgo et al., 2014). In addition, frontal zones are generally assumed to maximize diversity due to the convergence of species inhabiting different water masses (e.g. 61 Acha et al., 2004).

Tropical and subtropical oceanic regions usually have a permanent thermocline, which prevents the mixing of surface and nutrient-rich deep waters, thus presenting low productivity

64 and planktonic biomass (Nybakken, 1997). Accordingly, the continental margin of the South 65 Brazil Shelf (SBS) $\left(21-34^{\circ} \mathrm{S}\right)$ is predominantly oligotrophic, depicted by the strong influence 66 of the Tropical Water (TW) driven by the Brazil Current (Brandini, 2006). However, a series

67 of quasi-permanent or episodic oceanographic processes disrupt the vertical stability of the 68 water column significantly increasing the availability of nutrients in the upper layers (Acha et 
al., 2004; Gaeta and Brandini, 2006). While others, such as the Plata Plume and the Patos Lagoon estuarine front, do not disrupt stratification, but inject nutrients in the area (Acha et al., 2004).

Among the processes that mainly increase the biological productivity in the SBS, it is worth mentioning the wind-driven coastal and shelf-break upwelling of the South Atlantic Central Water (SACW), as seen, for instance, in the inner shelf of Cape São Tomé $\left(21^{\circ} \mathrm{S}\right)$, Cape Frio (23 ${ }^{\circ} \mathrm{S}$ ), and Cape Santa Marta Grande (28 ${ }^{\circ}$ ) (Castro and Miranda, 1998; Möller et al., 2008; Campos et al., 2013). The biological activity is also enhanced by freshwater discharges of several estuaries along the coast, and largely by the Río de la Plata $\left(35-36^{\circ} \mathrm{S}\right)$ and Patos Lagoon $\left(32^{\circ} \mathrm{S}\right)$, which transports nutrient-rich waters northwards (Ciotti et al., 1995; Acha et al., 2004). Furthermore, the Subtropical Shelf Front (STSF), a density-compensated thermohaline subsurface front, which occurs over the shelf close to $32^{\circ} \mathrm{S}$, creates a region with high nutrient input, primary production, copepod and ichthyoplankton abundance (Piola et al., 2000; Muelbert et al., 2008; Acha et al., 2020). Additionally, the SBS is subject to episodic instabilities, such as eddies (Ito et al., 2016) and meanders of the Brazil Current (Lorenzzetti et al., 2009), which influence the distribution patterns of nutrients and planktonic organisms (Brandini, 2006).

Worldwide, the role of oceanographic fronts on the distribution of pelagic larvae has been investigated, for instance, along the coast (Belgrano et al., 1995), at topographically generated fronts (Shanks et al., 2002), across rings (Villar et al., 2015), and at estuarine fronts (Ayata et al., 2011), where fronts were responsible for aggregating, transporting, mixing or separating specific assemblages. However, much more focus has been given for its influence on holoplankters and fish larvae (e.g. Flint et al., 2002; Bakun, 2006; Ohman et al., 2012), where elevated plankton abundance, as well as faunal transitions, have been attributed to the presence of the fronts.

This study investigates the potential role of oceanographic fronts on the dynamics of the spring/summer benthic invertebrate larvae community along one of the Large Marine Ecosystems (LMEs), the South Brazil Shelf. The specific goals were (i) to identify frontal sites and their influence on the meroplankton abundance and composition, and (ii) to investigate associations between frontal types and distinct taxonomic groups of larvae. The central hypothesis is that meroplanktonic high abundance patches occur at frontal sites, due to nutrient and chlorophyll- $a$ entrainment, and/or physical entrapment of these larvae.

\section{Materials and methods}


The South Brazil Shelf (SBS) extends from $22^{\circ} \mathrm{S}$ to $34^{\circ} \mathrm{S}$ along the South American southeast coast (Heileman and Gasalla, 2008) (Fig. 1A). The width of the continental shelf varies according to the latitude, being narrower in the northern than in the southern area (Fig. 1B). The continental slope is more pronounced in the northern region.

The SBS is often divided into three latitudinal subareas (Fig. 1B): (i) the Cape São Tomé-Cape Frio region (CSTF); (ii) the Southern Brazilian Bight (SBB) located between

112 Cape Frio and Cape Santa Marta Grande (CSM); and (iii) the Southern Subtropical Shelf 113 (SSS) between CSM and Río de la Plata. In the northern portion of SBS, the CSTF is mainly 114 characterized by seasonal coastal upwelling, while SBB and SSS are dominated by the strong 115 influence of less saline waters derived from the Río de la Plata and Patos Lagoon, which are 116 stronger in winter and spring (Burrage et al., 2008; Möller et al., 2008).

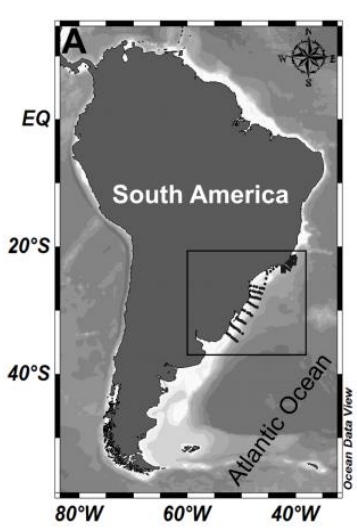

Figure 1. (A) Geographic location of the study area. (B) Position of the sampling stations along the 14 cross-shelf transects $(T)$. Subareas: CSTF = Cape São Tomé-Cape Frio; SBB = Southern Brazilian Bight; SSS = Southern Subtropical Shelf. Plankton samples were collected at 89 stations (black circles) out of 107 stations. Grey circles represent stations where only CTD data was available.

\section{Brazil}
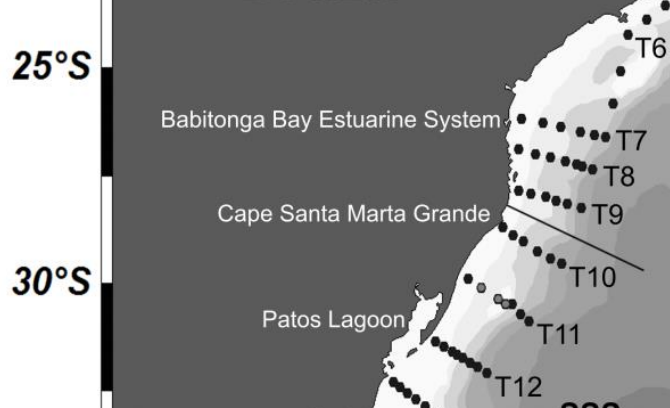

SBB
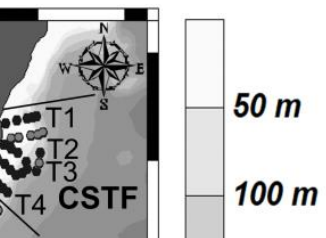

4 CSTF

$500 \mathrm{~m}$

$1000 \mathrm{~m}$

$2000 \mathrm{~m}$

$3000 \mathrm{~m}$

$4000 \mathrm{~m}$

$5000 \mathrm{~m}$
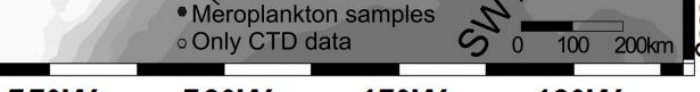
. 
Oceanographic cruises were conducted between Chuí $\left(34^{\circ} \mathrm{S}\right)$ and Cape São Tomé $\left(21^{\circ} \mathrm{S}\right)$ on board of the R. V. Cruzeiro do Sul (owned by the Brazilian Navy). To cover the entire sampling area three consecutive legs were carried out, with the first and second occurring in austral late spring (December 06 to 14 and 17 to 22, 2010) and the third finishing in early summer (January 04 to 11, 2011) in the CSTF region. The positions of CTD stations were strategically selected to intersect several shelf fronts that could be seen on satellite images. Prior to the cruises, high-resolution $(\sim 1 \mathrm{~km})$ ocean colour and thermal infrared satellite images were analysed for choosing locations of CTD stations. Vertical profiles of temperature, salinity, fluorescence and dissolved oxygen were recorded at 107 stations distributed at 17 cross-shelf transects using a SeaBird CTD (conductivity, temperature and depth) profiler casts (Fig. 1B). During the cruises, continuous measurements of sea surface ( $5 \mathrm{~m}$ ) temperature and salinity were made by a well-calibrated thermosalinograph. CDT measurements were only considered at depths greater than $10 \mathrm{~m}$.

In addition, water samples were collected at selected depths (3 or $5 \mathrm{~m}$, maximum fluorescence depth and base of the thermocline) to determine chlorophyll- $a$ and nutrient concentrations with 5-L Niskin bottles. Water was filtered on board and chlorophyll-a concentrations were determined by spectrophotometry using the approach detailed in Strickland and Parsons (1972). Ammonia and phosphate concentrations were determined by colorimetric analyses using a portable spectrophotometer, while nitrite, nitrate, and silicate were analyzed using Flow Injection Analysis. Nutrient analysis followed the processing recommendations in Aminot and Chaussepied (1983).

Plankton samples (89, black circles in Fig. 1B) were collected at 14 out of 17 crossshelf transects through vertical tows from the maximum fluorescence depth up to the surface in deep-water stations, from $10 \mathrm{~m}$ above the bottom when the water column was homogenous and from about $10 \mathrm{~m}$ depth at shallow stations (up to $20 \mathrm{~m}$ ).

A WP2 net with a $0.5-\mathrm{m}$ diameter mouth and $200-\mu \mathrm{m}$ mesh equipped with a flowmeter (General Oceanics) was used for sampling planktonic organisms, through vertical tows at a speed of about 2 knots. All samples were immediately fixed and preserved in $4 \%$ buffered seawater-formaldehyde solution. The maximum fluorescence depth ranged from 7 to $125 \mathrm{~m}$, and the plankton sampling depth ranged from 12 to $130 \mathrm{~m}$. The distance of sampling locations from the coast ranged from 7 to $418 \mathrm{~km}$. Local depths varied from 15 to $2,800 \mathrm{~m}$, thus covering coastal, shelf and oceanic waters.

Invertebrate larvae were counted and sorted from all 89 samples. In a few coastal stations, larvae were counted out of $1 / 2$ or $1 / 4$ fractions of the samples due to high 
160 abundances, and values further extrapolated. Larvae were identified into major taxonomic groups, under stereomicroscope, according to Smith (1977), Boltovskoy (1981) and Young (2001).

\subsection{Data analysis}

Larval counts were standardized to number of individuals per $100 \mathrm{~m}^{3}$ to calculate the relative abundance (RA) of each taxon. The frequency of occurrence (FO) was also calculated.

A potential temperature-salinity $(\mathrm{T}-\mathrm{S})$ diagram was built for the studied area on

Ocean Data View (Schlitzer, 2009). Water masses were determined based on thermohaline indexes in Miranda (1985), Castro and Miranda (1998), Piola et al. (2000), and Möller et al. (2008). Temperature and salinity obtained with the thermosalinograph were used as proxies to detect fronts in the study area (Chaigneau and Morrow, 2002). Chlorophyll- $a$ and nutrient data were also examined to detect responses to the fronts and some profiles are presented.

In addition to in situ data, we used 8-days satellite images of sea surface chlorophyll- $a$ concentration for the dates of each leg of the oceanographic cruises, with a $4 \mathrm{~km}$ spatial resolution from the MODIS Aqua sensor. Images were obtained through the Giovanni/NASA web site (Berrick et al., 2009).

In order to verify the distribution of the most frequent taxa in relation to environmental variables, a distance-based Redundancy Analysis (dbRDA) was conducted, using the BrayCurtis index for similarity between samples. Biological data were Hellinger-transformed to reduce the wide disparity in magnitude between taxa abundances (Legendre and Gallagher, 2001). Only the most frequent taxa were considered (> 10\%). In order to avoid collinearity of explanatory variables, we applied a variance inflation factor (VIF) and removed collinear variables. A cut-off VIF value of 10 was applied to get the final set of covariates (Zuur et al., 2009). The dbRDA and additional tests were performed in R (R Foundation for Statistical Computing), with the 'vegan' and 'HH' packages (Oksanem et al., 2013; Heiberger, 2013).

Additionally, a variance partitioning estimated from the dbRDA allowed to assess the relative amount of variance of the meroplankton abundance into components explained solely by effects of environmental or spatial variables, components explained by combined effects of environmental and spatial variables, and finally unexplained components (Borcard et al., 1992). The spatial variables used were selected from Brandão et al., 2015, where principal coordinates of neighbor matrices (PCNM) were applied in order to identify the most 
194 predominant spatial patterns (Borcard et al., 2004). Package 'vegan' (Oksanem et al., 2013) 195 was used for variation partitioning.

Mean values of temperature, salinity, chlorophyll- $a$ and nutrient concentrations, calculated from the surface down to the plankton sampling depth, were used in the dbRDA.

198 The oxygen vertical gradient was calculated using the surface oxygen value and the value at 199 the bottom of the oxycline, as well as respective depths. These parameters were used in the 200 dbRDA to characterize the environmental scenarios where meroplankton was distributed.

\section{Results}

203

\subsection{Physical and biological features of the fronts}

The $\mathrm{T}-\mathrm{S}$ diagram in the range $0-130 \mathrm{~m}$ (maximum plankton sampling depth) showed the presence of six water masses (Fig. 2): Tropical Water (TW), Shelf Water (SW), Subtropical Shelf Water (STSW), Plata Plume Water (PPW), South Atlantic Central Water (SACW), and Subantarctic Shelf Water (SASW).

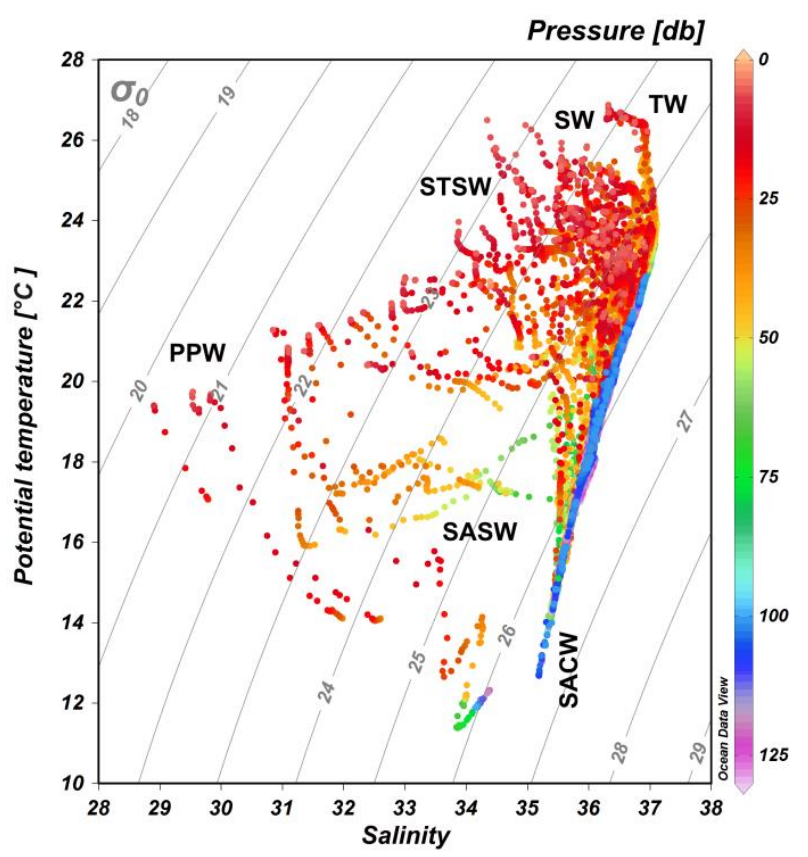

212 Figure 2. Potential temperature-salinity diagram for the first $130 \mathrm{~m}$ of all stations along the South 213 Brazil Shelf during late spring 2010 and early summer 2011. TW = Tropical Water; SW = Shelf 214 Water; STSW = Subtropical Shelf Water; PPW = Plata Plume Water; SACW = South Atlantic Central 215 Water; SASW = Subantarctic Shelf Water. 
The cross-shelf distribution of temperature and salinity are shown vertically until 200 $m$ depth (Fig. 3) and through high-resolution surface data (Fig. 4), together with meroplankton abundance.

The salty and warm Tropical Water (TW) was the dominant water mass in the surface layer over the slope area in the entire region (Fig. 3). Great variability was observed regarding the depth of the cool nutrient-rich South Atlantic Central Water (SACW). The isotherms of $20^{\circ} \mathrm{C}$ and $18.5^{\circ} \mathrm{C}$ define the upper limit below which the SACW dominates the bottom layers over the shelf in the CSTF (Fig. 3A-F) and SBB/SSS (Fig. 3G-N), respectively. The strongest onshore intrusions of the SACW were observed at T2, T5 (Cape Frio), T9 and T10 (Cape Santa Marta Grande) (Fig. 3B, E, I and J), depicting the upwelling in subsurface waters. In the Southern portion, the estuarine plume, especially represented by the lowsalinity Plata Plume Water (PPW), was observed over the shelf from T12 to T14 (Fig. 3L-N), occupying a larger area along T13 (Patos Lagoon) and T14. In the southmost transect, the Subantarctic Shelf Water (SASW) was present below $30 \mathrm{~m}$ (Fig. 3N).

Pelagic larvae of benthic invertebrates were present in all samples, with mean abundance of $1,350 \pm 320$ larvae $/ 100 \mathrm{~m}^{3}$. The highest abundance patches of meroplankton were found in the upwelling zone of Cape Santa Marta Grande (T10) $\left(19,250\right.$ larvae/100 $\left.\mathrm{m}^{3}\right)$, in the estuarine front at Patos Lagoon's mouth (T13) $\left(13,550\right.$ larvae/100 $\left.\mathrm{m}^{3}\right)$, in the Subtropical Shelf Front (STSF), located at T14 (12,430 larvae/100 $\left.\mathrm{m}^{3}\right)$, and in the coastal realm of T6 (10,400 larvae/100 $\mathrm{m}^{3}$ ) (Fig. 3 and Fig. 4). At T10 and T6, meroplankton abundance peaks were coincident with the upwelling of the SACW (Fig. 3F and J). At T10, the area subject to the upwelling front was characterized by high concentrations of nitrate and phosphate (Fig. 5F and G). In the area of the STSF, the plankton tow coincided with the zone of a sharp change in salinity and temperature (Fig. 3N and Fig. 4N) due to intrusion of SASW into the area. In some cases, meroplankton high abundance patches over the oceanic waters coincided with nocturnal plankton hauls, as seen in offshore stations of T1, T6 and T11 (Fig. $3 \mathrm{~A}, \mathrm{~F}$ and $\mathrm{K})$.

Several small-scale surface fronts were identified along the shelf (Fig. 4), and their putative influence on the meroplankton abundance varied throughout the region. For instance, along T12, the increase in meroplankton abundance (3-fold) seems to be associated with the quick increase in salinity $(\Delta \mathrm{S} \sim 3.0)$ and temperature $\left(\Delta \mathrm{T} \sim 2^{\circ} \mathrm{C}\right)$ between stations (Fig. $\left.4 \mathrm{~L}\right)$. In addition, at $\mathrm{T} 8$, the front $\left(\Delta \mathrm{S} \sim 1.0 ; \Delta \mathrm{T} \sim 1^{\circ} \mathrm{C}\right)$ also coincided with an increase in meroplankton abundance (2-fold) (Fig. 4H). And at T1 the increase in meroplankton relative abundance (3-fold) was coincident with the thermohaline front $\left(\Delta \mathrm{S} \sim 0.7 ; \Delta \mathrm{T} \sim 4^{\circ} \mathrm{C}\right)$ (Fig. 
251 4A). On the other hand, despite the thermal front $\left(\Delta \mathrm{T} \sim 3^{\circ} \mathrm{C}\right)$ observed at $\mathrm{T} 2$, meroplankton 252 abundance was virtually the same between stations (Fig. 4B).

During the cruises, the ship crossed two cyclonic eddies over the shelf zone (Ito et al., 254 2016). The first cyclonic eddy-like structure was found in the offshore area of T14, whereas 255 the second was identified offshore T3 (Fig. 4C and N). The cyclonic eddy at T14 section was 256 smaller and weaker than at T3 section (Ito et al., 2016). At T3, the cyclonic vortex was strong 257 enough for upwelling of the SACW from deep layers up to about $50 \mathrm{~m}$ deep as well as the 258 maximum chlorophyll- $a$ depth (see Fig. 3C and Fig. 5A), and for aggregating nutrients (Fig. 259 5B-D). Despite plankton sampling was carried out in shallower waters $(\sim 30 \mathrm{~m})$, a slightly 260 increase in meroplankton relative abundance was observed (Fig. 4C and Fig. 5A).

261 High relative abundances of meroplankton were mainly associated with the coastal 262 zone, seen in several transects (Fig. 4A, B, H, I and K). In the mouth of Patos Lagoon (T12) 263 an estuarine and a plume front were observed (Fig. 4M), and meroplankton patches were 264 observed until almost $200 \mathrm{~km}$ from the coast, where chlorophyll- $a$, phosphate and silicate 265 concentrations were also high down to $100 \mathrm{~m}$ deep (Fig. 5I, K and L). At T14, high 266 abundances of meroplankton were observed in two stations, one related with the presence of 267 the STSF (Fig. 3N), where high concentrations of nitrate and phosphate were observed (Fig. $2685 \mathrm{~N}$ and $\mathrm{O}$ ); and the other associated with the occurrence of the eddy (Fig. 3N and Fig. 4N), 269 depicted by a chlorophyll- $a$ bloom (Fig. 5M). 

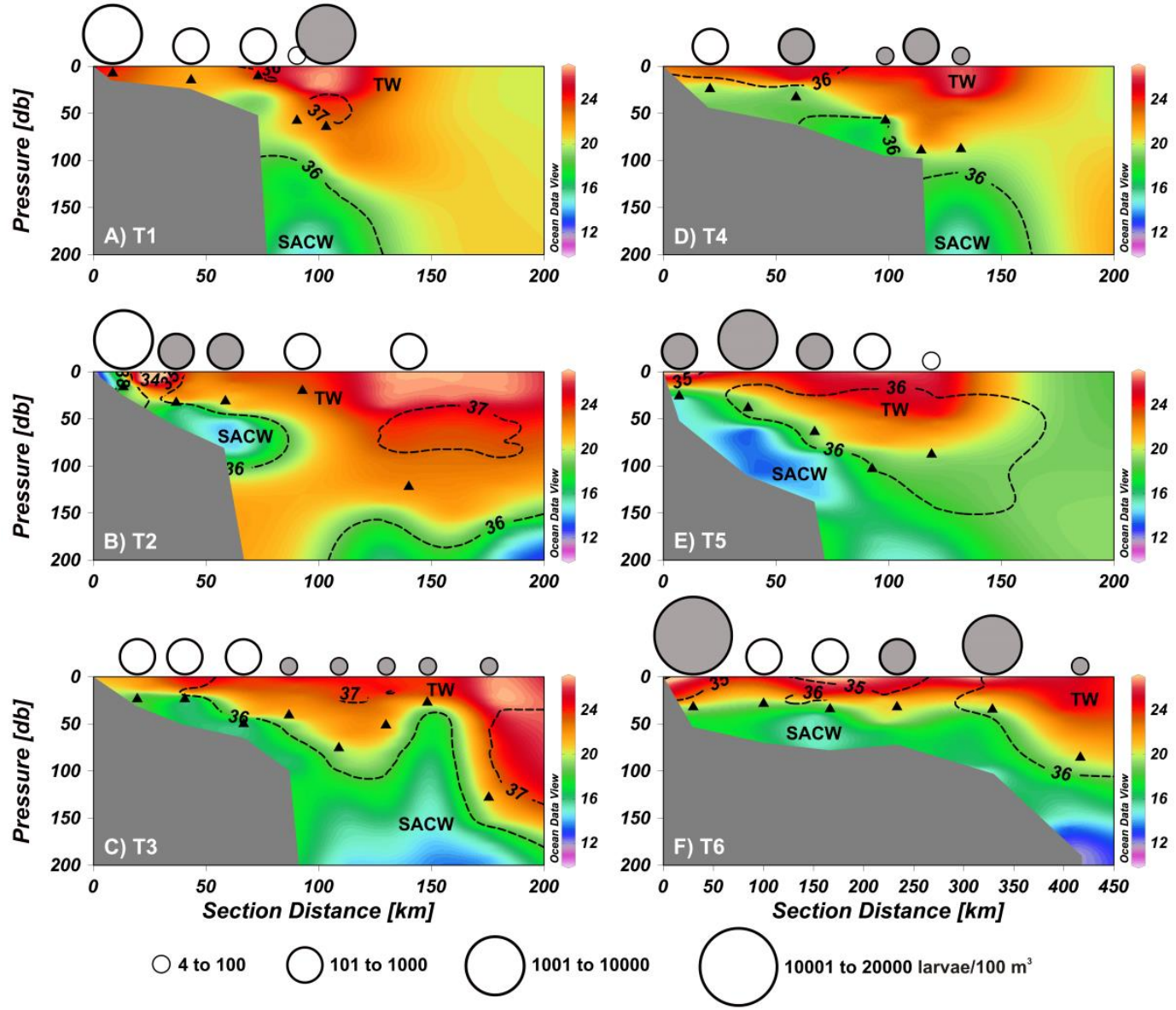

272 Figure 3. Cross-shelf distributions of temperature $\left({ }^{\circ} \mathrm{C}\right)$ (colors), salinity (contour lines) and 273 meroplankton abundance (larvae/100 $\mathrm{m}^{3}$ ) (circles) for the transects along the South Brazil Shelf.

274 Circles filled in gray represent stations conducted at night. Black triangles indicate the plankton 275 sampling depth, which was coincident or below (from 1 to $10 \mathrm{~m}$ ) the maximum fluorescence depth. 276 White triangles indicate the maximum fluorescence depth in stations where it was below plankton sampling depth (T8 and T11). 

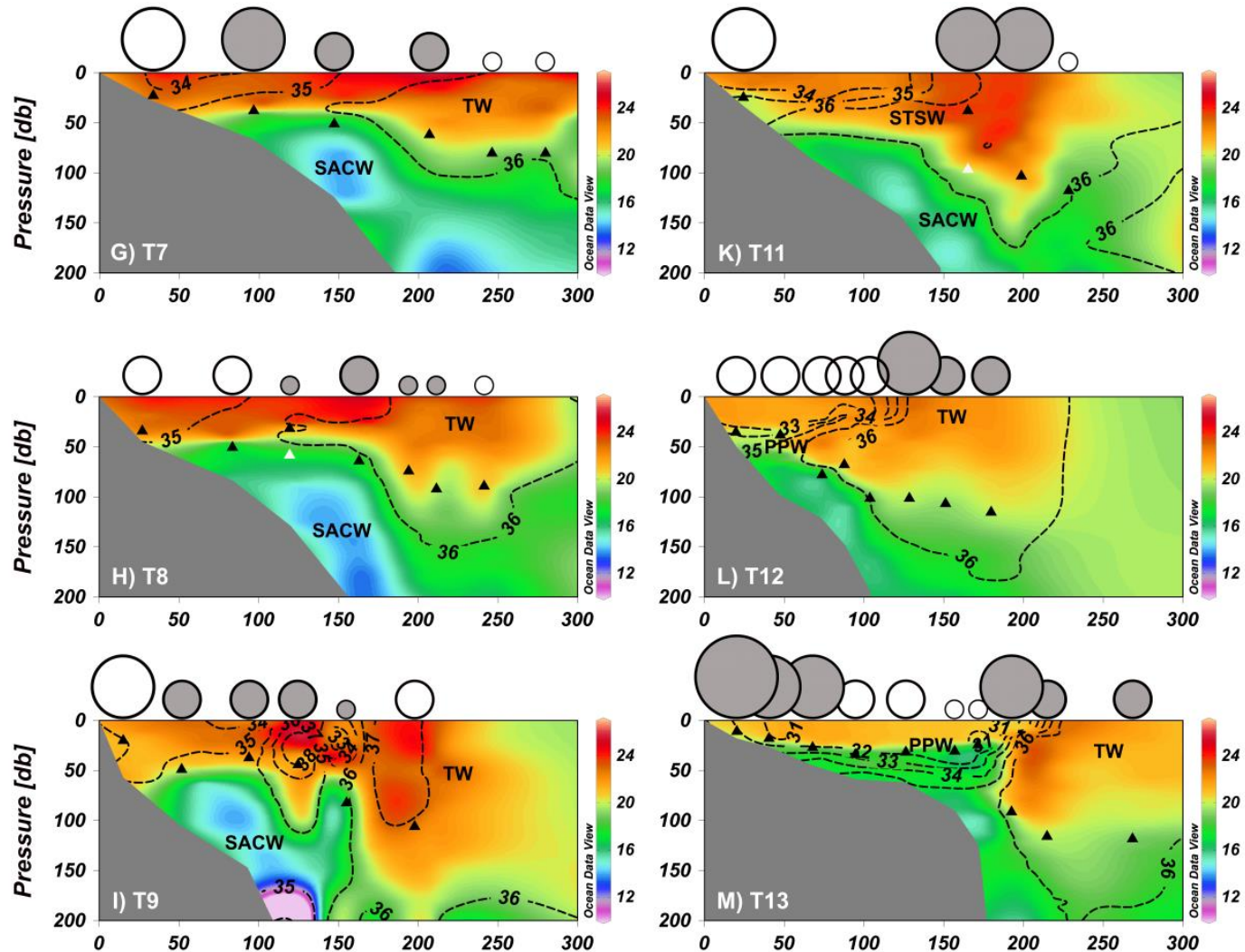

281 Figure 3. (Continued). 

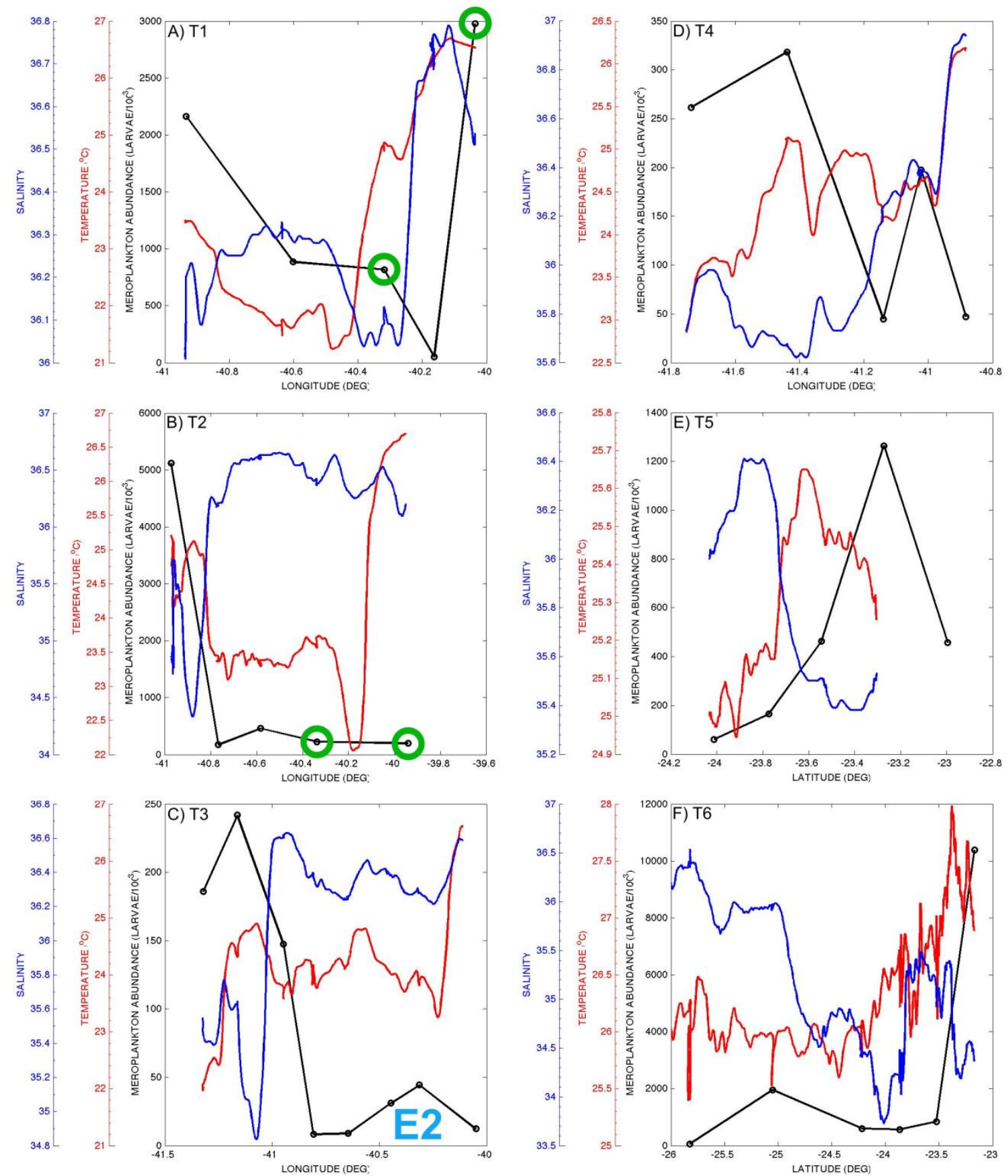

Figure 4. Surface salinity and temperature variability obtained from the thermosalinograph and meroplankton abundance (larvae/100 $\mathrm{m}^{3}$ ) by each transect along the South Brazil Shelf. Note that for T5 and T6 the sections are exceptionally shown by latitude, from South to North. Eddies position (E1 and E2) according to Ito et al. (2016). Green circles indicate the variation in meroplankton abundance and the corresponding limits of the shelf fronts. 

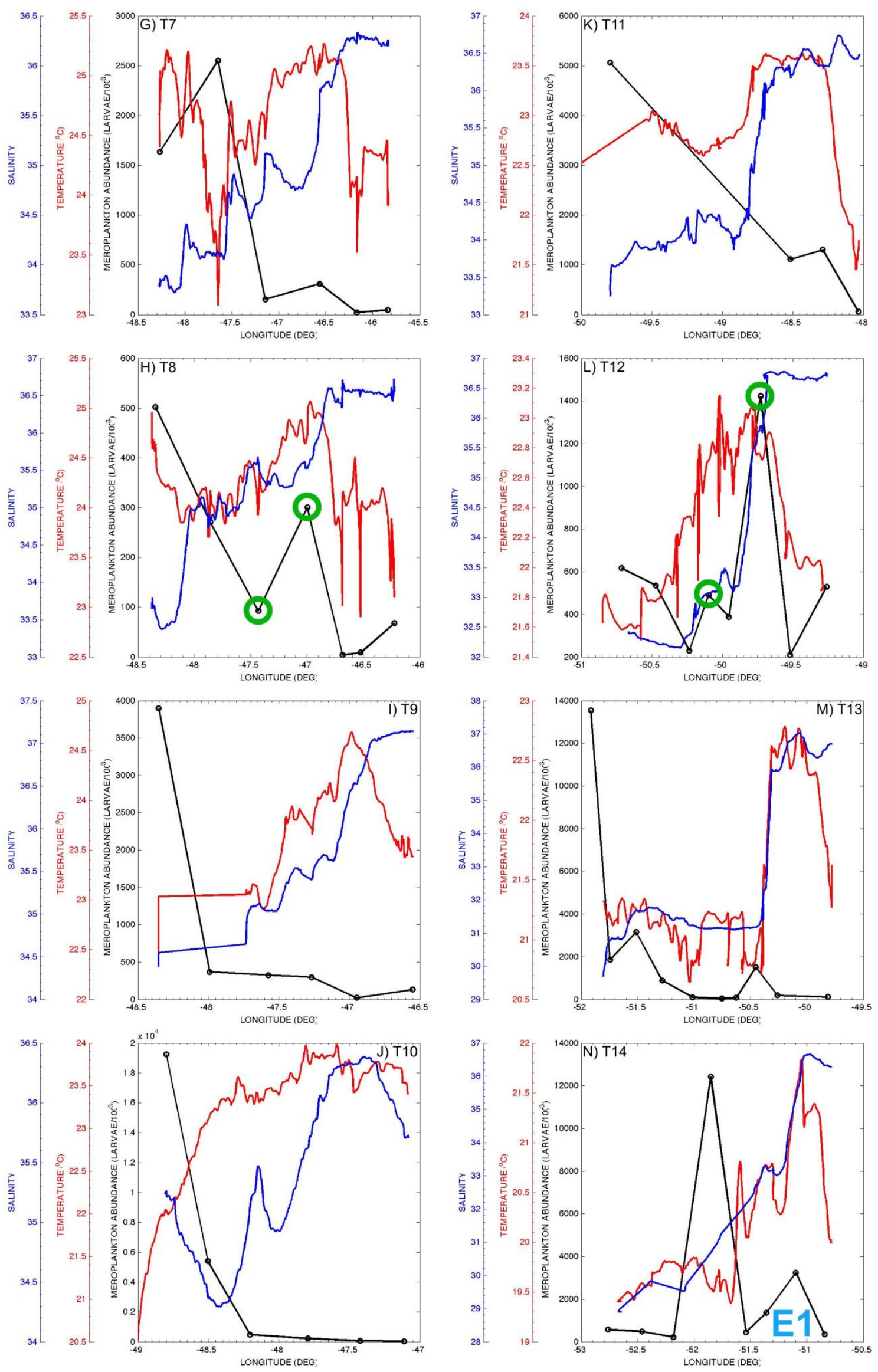

Figure 4. (Continued). 

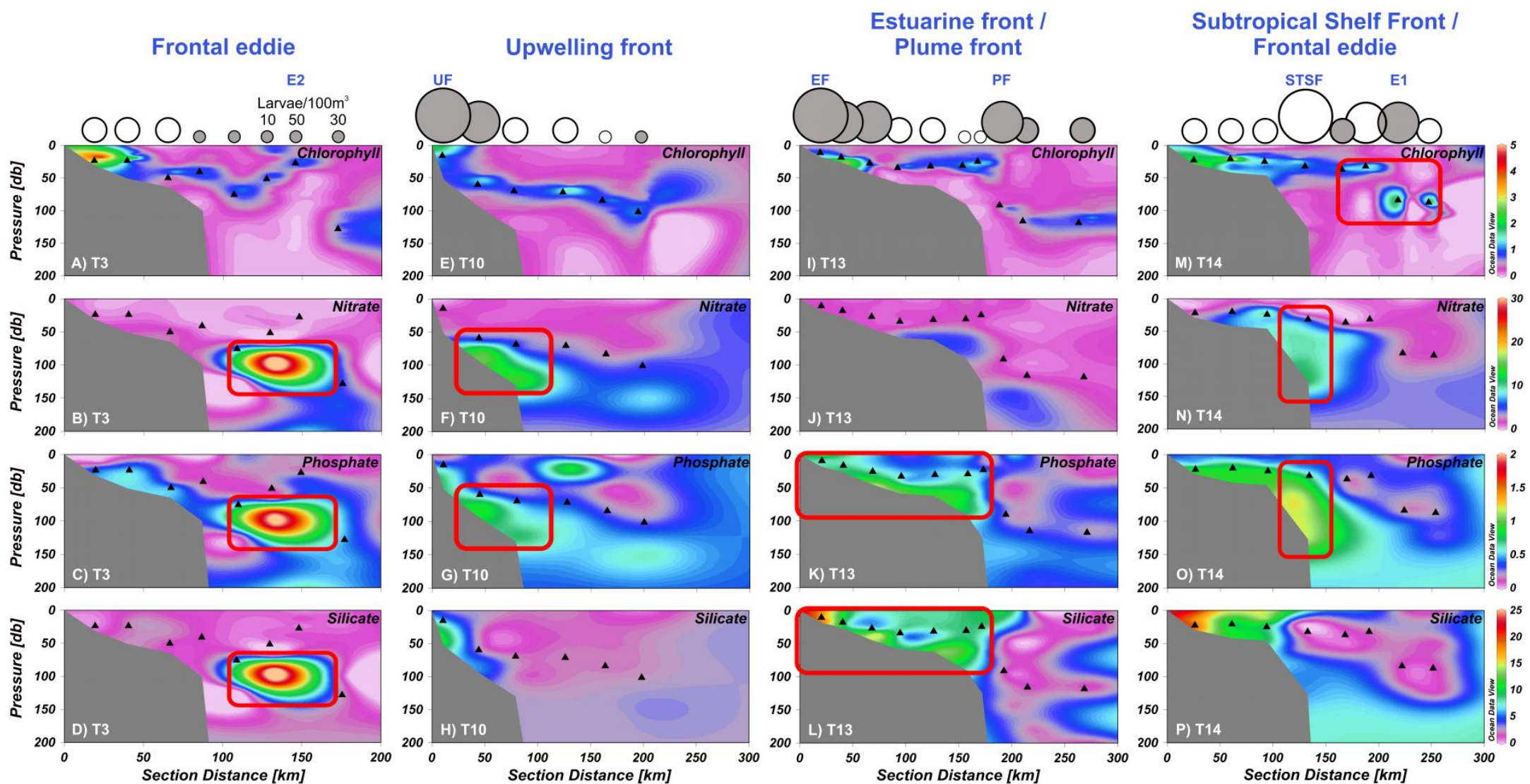

101 to 1000

$\bigcirc_{1001 \text { to } 10000}$

$\begin{array}{ccc}100 & 150 & 200 \\ \text { Section Distance } & {[\mathrm{km}]}\end{array}$

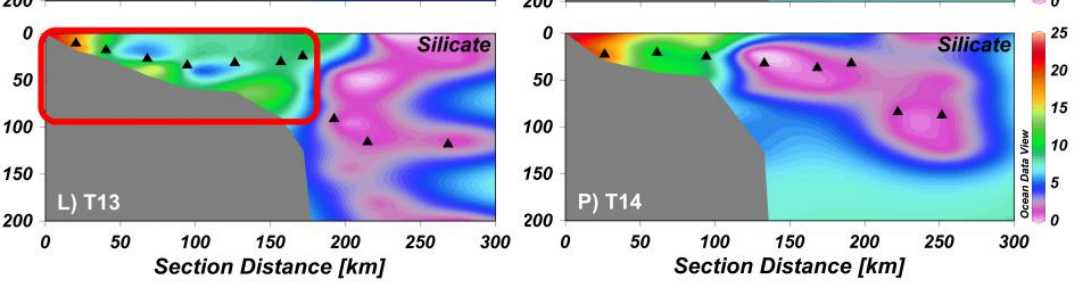

Figure 5. Cross-shelf distributions of meroplankton abundance (larvae $\left./ 100 \mathrm{~m}^{3}\right)$ (circles), chlorophyll- $a\left(\mathrm{mg} / \mathrm{m}^{3}\right)$, nitrate $(\mu \mathrm{M})$, phosphate $(\mu \mathrm{M})$ and silicate $(\mu \mathrm{M})$ at T3, T10, T13 and T14. Circles filled in gray represent stations conducted at night. Black triangles indicate the plankton sampling depth. Eddies position (E1 and E2) according to Ito et al. (2016). UF = upwelling front; EF = estuarine front; PF = plume front; STSF =

Subtropical Shelf Front. Red rounded rectangles indicate chlorophyll- $a$ or nutrient peaks in the area of the fronts. 
304

305

306

307

308

309

Overall, the surface chlorophyll- $a$ concentration and the meroplankton abundance were high all along the continental shelf with maximum values in inshore waters. It was also high over the entire shelf of the southernmost transects (Fig. 6), under the influence of the PPW (Fig. 3L-N).

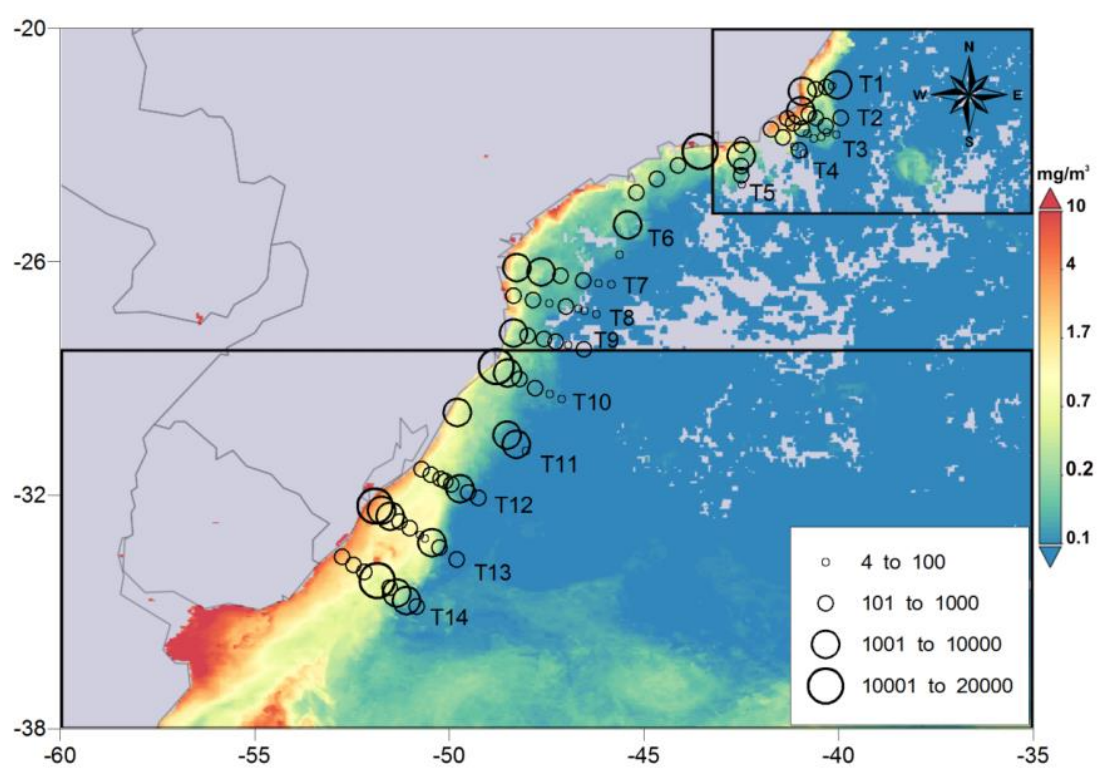

Figure 6. Meroplankton abundance (black circles) (larvae/100 $\mathrm{m}^{3}$ ) along the South Brazil Shelf during December 2010 and January 2011. In the background, 8-days satellite images of chlorophyll-a concentration are shown for the three legs of the cruise. Leg 1 corresponds to the bottom rectangle, sampled in December 06 to 14, 2010. Leg 2 occurred in December 17 to 22, 2010, during which transects 6 to 9 have been sampled. Leg 3 took place in January 04 to 11, 2011, represented by the upper rectangle.

\subsection{Meroplankton community composition across the fronts}

Larvae belonging to eleven phyla were found in the area. Among the groups, decapod larvae were the most frequent, while gastropod larvae were the most abundant, followed by larvae of polychaetes and bivalves, with these four groups accounting together for $80 \%$ of total larval abundance (Table 1). Besides these groups, cirripedes, holothurians and ophiuroids also presented relatively high mean larval abundance comparing to the others ( 50 larvae $\left./ 100 \mathrm{~m}^{3}\right)$.

Polychaete larvae presented up to 100 larvae $/ 100 \mathrm{~m}^{3}$ in most samples. Abundance hotspots of these larvae were observed in the coastal stations of T13 and T10 ( 7,000 and 4,000 larvae/100 $\mathrm{m}^{3}$, respectively), as well as at T14, near the STSF area ( 5,000 larvae/100 
$329 \mathrm{~m}^{3}$ ) (Fig. 7A) (Table 2). In turn, molluscan larvae were found in most samples with 330 abundances of up to 1,000 larvae $/ 100 \mathrm{~m}^{3}$. Their highest abundances $\left(\sim 8,000\right.$ larvae $\left./ 100 \mathrm{~m}^{3}\right)$ 331 occurred in the nearshore stations of T6 (mostly gastropods) and T10 (mostly bivalves), and 332 at T14, at the same station of polychaete larval peak (mostly gastropods) (Fig. 7B; Fig. 8). 333 Crustacean larvae showed a clear pattern of decrease in abundance towards the ocean (Fig. 334 7C), with the highest values in the coast of T2 and T13 transects (decapods and cirripedes) ( 3353,300 and 2,500 larvae/100 $\mathrm{m}^{3}$, respectively) (Fig. 7C; Fig. 8). For the detailed distribution of 336 decapod larvae in the area, see Brandão et al. (2015). Echinoderm larvae were found in high 337 abundances (up to 4,600 larvae/100 $\mathrm{m}^{3}$ ) only in a few coastal stations located southward $27^{\circ} \mathrm{S}$ 338 (Fig. 7D), among which ophiuroids and holothurians were the most representative (Fig. 8; 339 Table 1). 

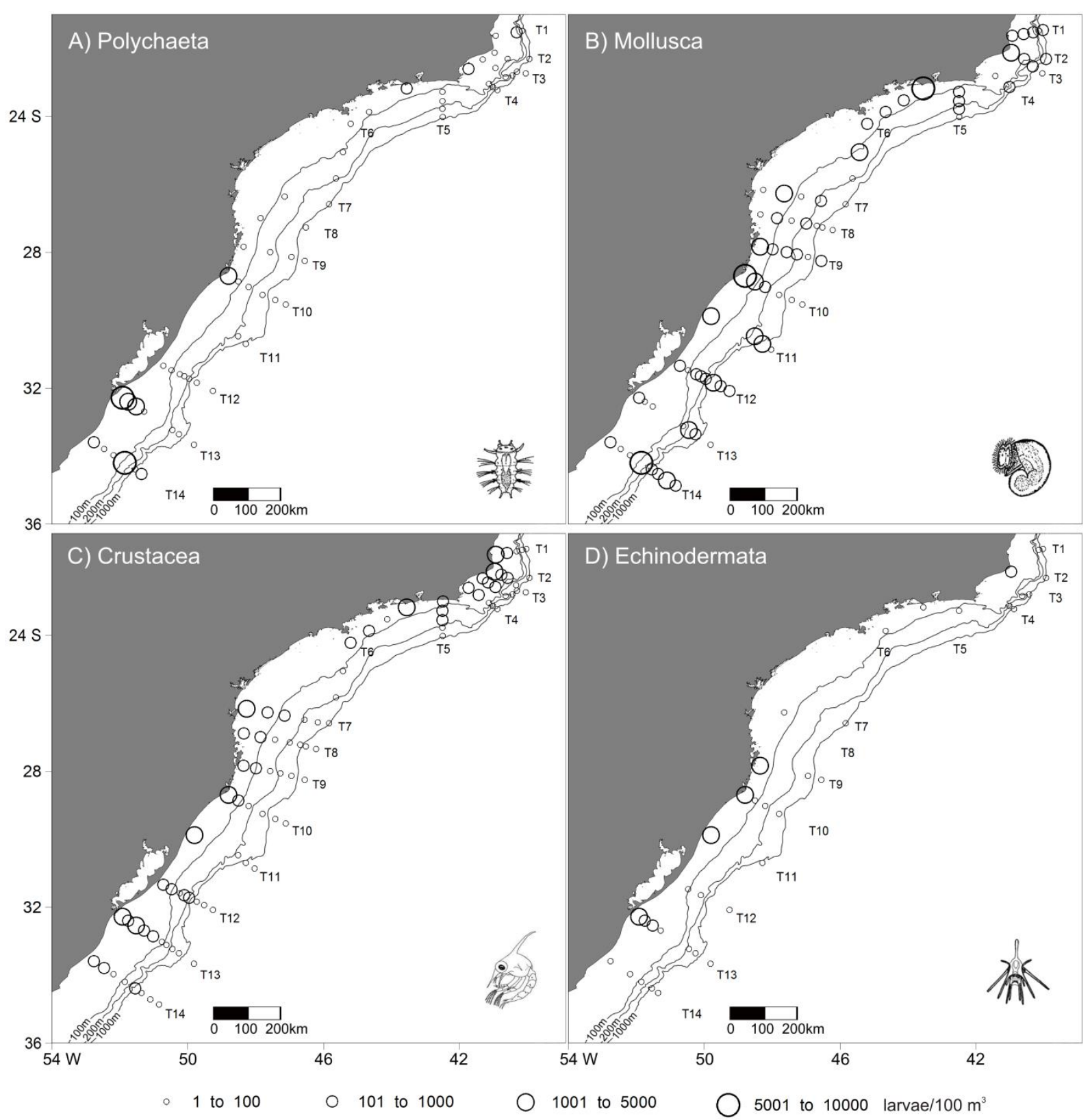

342 Figure 7. Distribution of larval abundance (larvae/100 m3) of: (A) Polychaeta, (B) Mollusca, (C)

343 Crustacea and (D) Echinodermata in the 89 stations sampled along the South Brazil Shelf. 

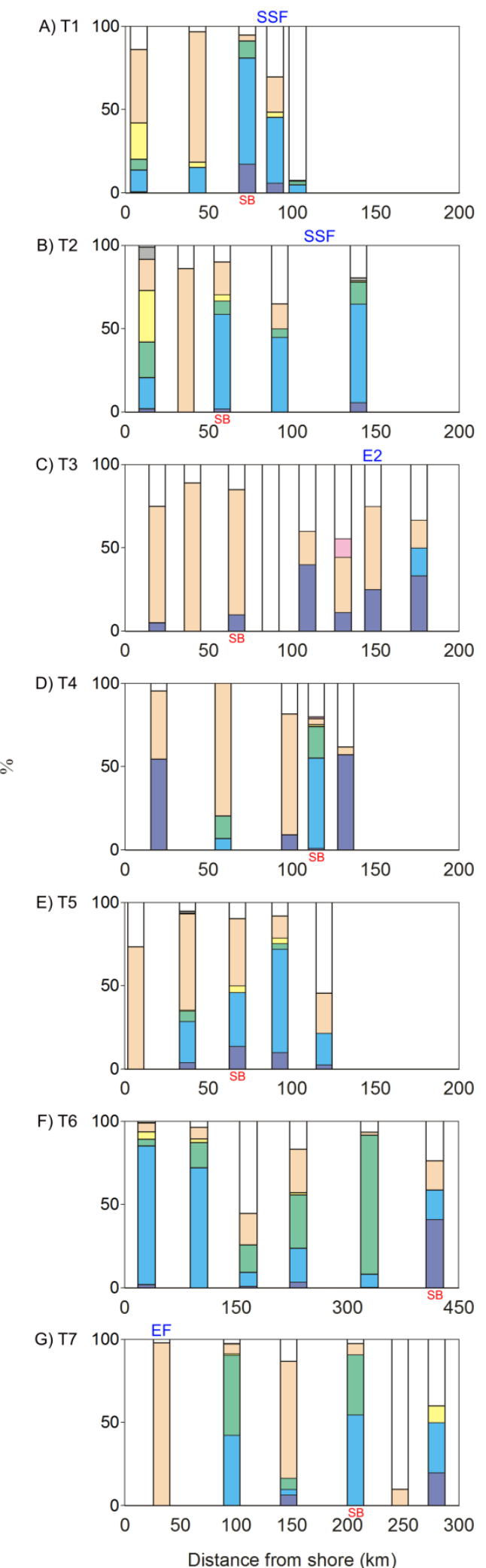
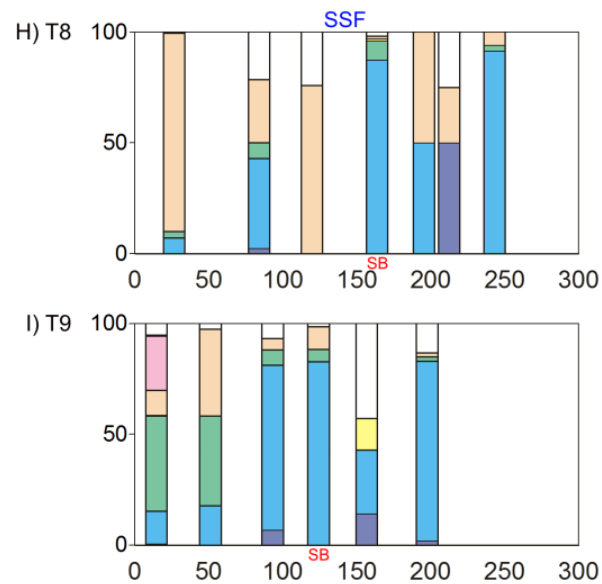

J) T10 100 UF
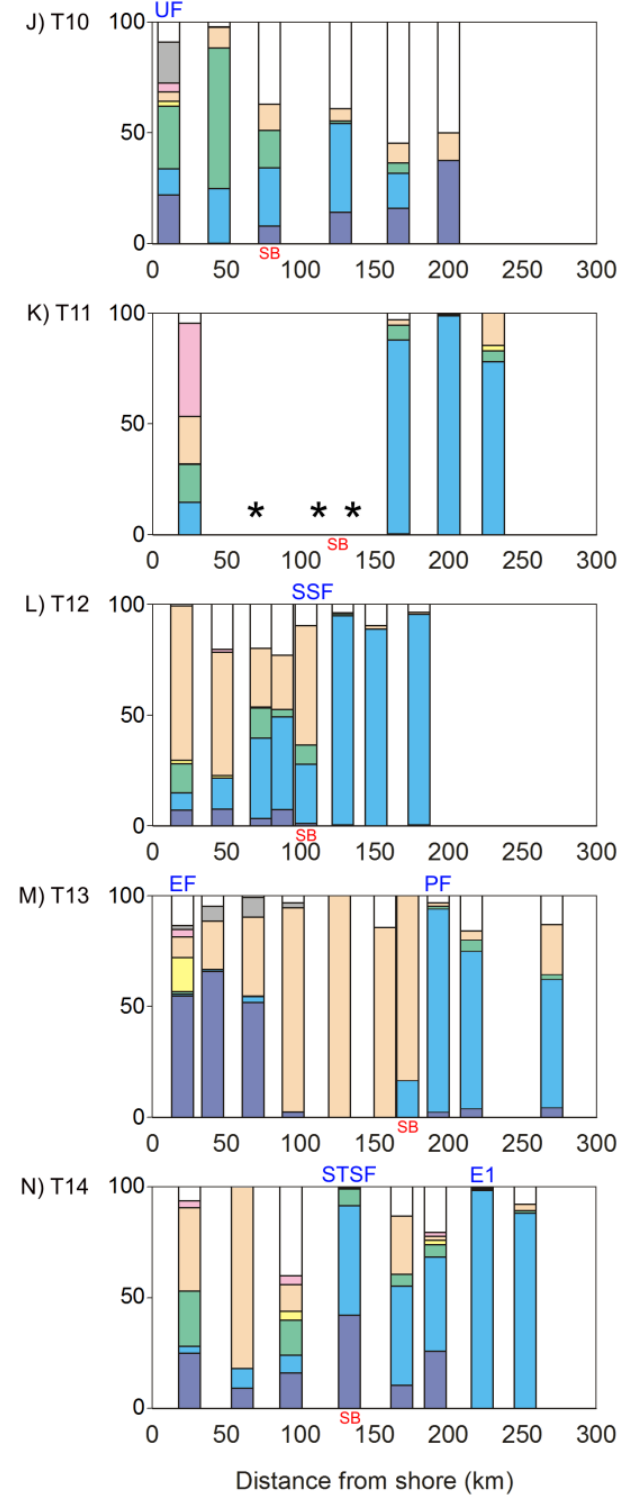

$\square$ Polychaeta $\square$ Grastropoda

$\square$ Bivalvia

$\square$ Cirripedia

$\square$ Decapoda

$\square$ Ophiuroidea

Holothuroidea $\square$ Other larvae

Figure 8. Cross-shelf relative abundance (\%) of the main meroplankton groups found along the South

347 Brazil Shelf, showing the approximate location of the shelf break (SB) and fronts. SSF $=$ small-scale

348 front; $\mathrm{EF}$ = estuarine front; $\mathrm{PF}=$ plume front; $\mathrm{UF}=$ upwelling front; STSF = Subtropical Shelf Front.

349 Eddies position (E1 and E2) according to Ito et al. (2016). Asterisks indicate stations without plankton 
Regarding the influence of environmental variables on the distribution of the most frequent meroplankton groups, the first and second axes of the distance-based Redundancy Analysis (dbRDA) ordination accounted together for $65.5 \%$ of the constrained variance (Fig. 9). Axis 1 represented mainly the cross-shelf gradient. It was positively correlated with chlorophyll- $a$ concentration and oxygen stratification, and negatively with bathymetry, distinguishing neritic from oceanic assemblages. Larvae of gastropods showed an association with offshore conditions. In contrast, crustacean larvae appeared in association with chlorophyll-rich oxygen-stratified coastal waters (Fig. 9).

Axis 2 represented the nutrient-rich waters, especially in ammonia, silicate and phosphate, in opposition to the nutrient-poor waters, characterized by high salinity and temperature. This separation seems to be associated with the contrasting conditions between the PPW, which occupies the neritic waters in the south, and the Tropical Water (TW), dominant over the slope. Larvae of polychaetes and echinoderms were strongly associated with the estuarine plume waters (Fig. 9).

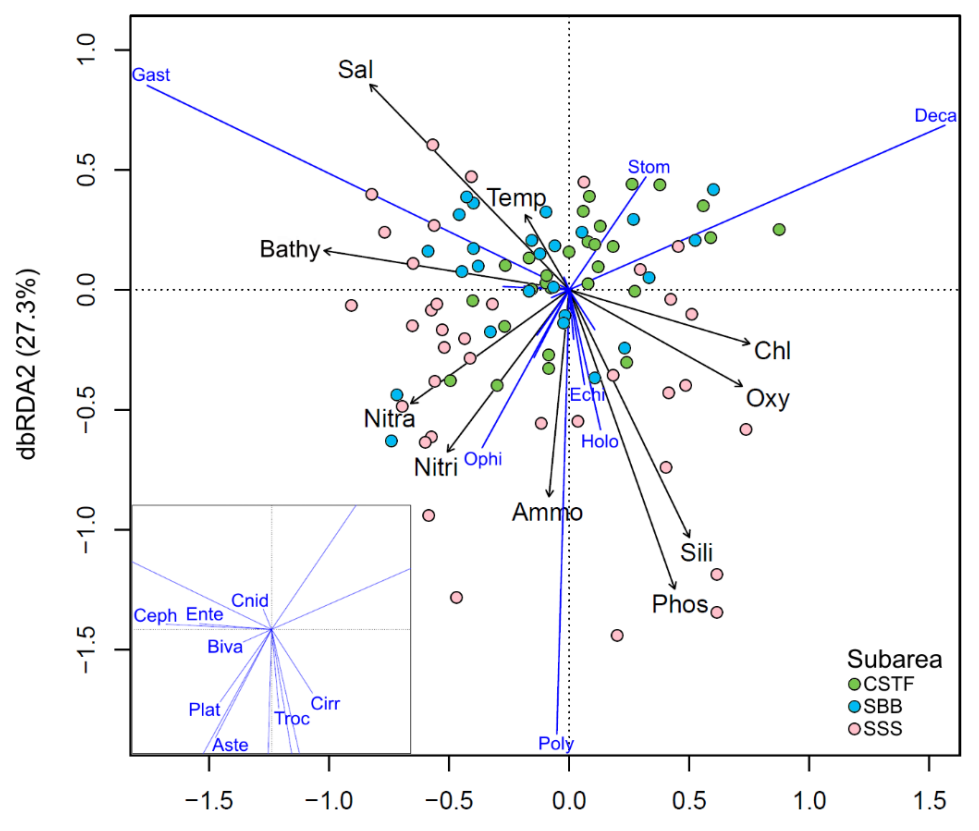

dbRDA1 (38.2\%)

368 Figure 9. Distance-based Redundancy Analysis (dbRDA) ordination for meroplankton composition in 369 relation to environmental variables. Triplot with explanatory variables, taxa and samples (colored by 370 latitudinal subarea). Taxa: Gast = Gastropoda; Stom = Stomatopoda; Deca $=$ Decapoda; Ophi $=$ 371 Ophiuroidea; Echi = Echinoidea; Holo = Holothuroidea; Poly = Polychaeta Ceph = Cephalopoda; 372 Ente $=$ Enteropneusta $;$ Cnid $=$ Cnidaria; Biva = Bivalvia; Plat $=$ Platyhelminthes ; Aste = Asteroidea; 373 Troc $=$ Trocophores; Cirr $=$ Cirripedia. Explanatory variables: Bathy $=$ bathymetry; Sal $=$ salinity; 
Temp $=$ temperature $;$ Nitra $=$ nitrate $;$ Nitri $=$ nitrite $;$ Ammo $=$ ammonia $;$ Phos $=$ phosphate $;$ Sili $=$ silicate; Oxy = oxygen; $\mathrm{Chl}=$ chlorophyll- $a$. Subareas: CSTF = Cape São Tomé-Cape Frio; SBB = Southern Brazilian Bight; SSS = Southern Subtropical Shelf.

In summary, the coastal realm was generally dominated by larvae of decapods, cirripedes and bivalves. In addition, gastropod and decapod larvae were the most representative larvae in small-scale shelf fronts (Table 2). In turn, larvae of polychaetes were the dominant in the estuarine front of Patos Lagoon section (T13) (Fig. 8, Fig. 9 and Table 2). In the upwelling front of Cape Santa Marta (T10), larvae of a higher number of taxa occurred, being mostly represented by Bivalvia, Gastropoda and Polychaeta (Fig. 8 and Table 2).

Variance partitioning indicated that most of the variation in invertebrate larval distributions is due to unexplained or stochastic variance. Of the explained portion, variation was mainly due to the combined effect of the environmental and spatial structure of the hydrological environment which accounted for $19 \%$ of the total variation. Environmental variables alone explained 8\%, while spatial variation retained 5\% (Fig. 10).

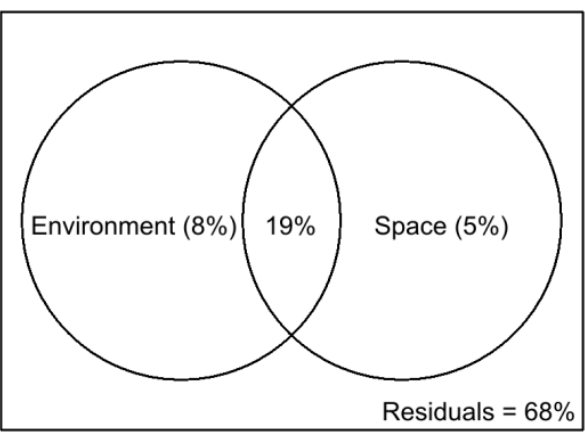

Figure 10. Venn diagram showing the results of the variation partitioning procedure.

\section{Discussion}

The present findings provide information on the distribution of pelagic larvae of several benthic invertebrate taxa and its relationship with oceanographic fronts within a wide latitudinal range in the South Brazil Shelf. The coast-ocean gradient was the most striking feature on the distribution of meroplankton along the area during spring 2010 and summer 2011. Meroplankton abundances were higher in the nearshore stations irrespectively of the latitudinal hydroclimatic scenarios. The contrast between the coastal water masses, rich in nutrients, and the dominant Tropical Water (TW) over the outer shelf and slope, seems to greatly contribute to this general pattern. Besides, the surface chlorophyll- $a$ concentration 
403

404

405

406

407

408

409

410

411

412

413

414

415

416

417

418

419

420

421

422

423

424

425

426

427

428

429

430

431

432

433

434

435

436

distribution was also coincident with the meroplankton abundance gradient. Similar coastocean gradients have also observed for meroplankton in the Southern Ocean (Thatje et al., 2003) or along a Patagonian fjord (Meerhoff et al., 2014), assigned mainly to nutrient and chlorophyll- $a$ inputs.

In addition to the cross-shelf gradient, meroplankton highest values were recorded at specific zones under the influence of distinct frontal systems. It is worth highlighting the frontal upwelling at Cape Santa Marta (CSM), where meroplankton presented a remarkable 20 -fold increase in relation to the neighboring stations. Coastal upwelling events in this area were observed most likely in response to NE winds (Möller et al., 2008), with strong intrusions of the South Atlantic Central Water (SACW). Thus, physical and chemical gradients are formed along shore between the upwelled water and the advected Coastal Water (CW) (Brandini et al., 2018). This promotes an increase in the productivity and food availability, particularly of diatoms (Brandini et al., 2014), ensuring the availability of food for the larvae. High abundances of bacterioplankton, fish eggs and larvae were also found in the area under the influence of CSM coastal upwelling (Fontes et al., 2018; Macedo-Soares et al., 2014). In addition, high biomass values of invertebrates were also observed in the area, notably gastropods, bivalves and polychaetes (Amaral and Rossi-Wongtschowski, 2004).

The estuarine and plume fronts at Patos Lagoon transect also presented an increase in meroplankton abundance, of more than 10-fold. Plata Plume Water (PPW) displays a wide range of physical and biogeochemical properties, as chlorophyll- $a$ and silicates (Ito et al., 2016), which reflect elevated nutrient availability due to both respiratory processes and subantarctic water mass contributions (Acha et al., 2004). Indeed, it has been shown to sustain high chlorophyll- $a$ concentrations and consequently high phytoplankton biomass (Ciotti et al., 1995; Möller et al., 2008), thus providing planktotrophic larvae with abundant food resources. Regarding the silicates, the high concentrations could be due also to river discharges, since continental freshwaters are characterized by high concentrations of silicates (Ciotti et al., 1995). In addition, river plumes and associated fronts also act as physical barriers for the dispersal of pelagic larvae, which may aid to concentrate or retain them in their vicinities (Largier, 2003).

It is also worth to point out the strong influence of the Subtropical Shelf Front (STSF) on the meroplankton abundance, presenting an increase of nearly 60-fold, coincident with a sharp change in temperature and salinity. The increase in meroplankton abundance is likely to be associated with high nutrient input (nitrate and phosphate) and primary production. High abundances of copepod and ichthyoplankton have also been registered in the area (Muelbert et 
al., 2008; Acha et al., 2018). This front could be compared to other shelf-break fronts, such as in the Middle Atlantic Bight (Marra et al., 1990) or in the northeastern North Sea (Munk et al., 1995), where increases were observed in phytoplankton concentration and fish larvae abundance, respectively. Consistently, the perturbations caused by the front bring turbid, nutrient-rich water into clearer water, making it more productive than elsewhere.

Close inspection of satellite thermal and color images show that the ship crossed two cyclonic vortices (Ito et al., 2016). Although only a slightly increase in meroplankton relative abundance was observed in the corresponding areas. The occurrence of cyclonic eddies in the Southern Brazilian Bight enriches nutrients at the bottom layer of the euphotic zone; therefore, regenerated production, a common feature of these oligotrophic waters, is temporarily replaced by new production, in which the nitrogen compound is primarily nitrate (Metzler et al., 1997; Ito et al., 2016). The episodic occurrence of vortices may indeed enhance the primary production and, consequently, zooplanktonic community in the area (Acha et al., 2004). In addition, eddy systems may act as retention areas for neritic invertebrate larvae, as seen in the shelf of Gran Canaria in the NW Africa (Landeira et al., 2009), and in the Gulf Stream (Anderson and Robinson, 2001), as well as for holoplankton, as seen in the North Pacific (Mackas et al., 2005). For fish larvae, both physical trapping and biological attraction to food contribute to the retention of fish larvae in eddies in the North Pacific (Chang et al., 2018).

Several other small-scale thermal and saline shelf fronts were detected during the studied period, primarily in the surface and, secondarily, in the subsurface waters. Although the extent of their influence was not consistent, varying between no influence to a 3 -fold increase, in most of the areas, higher values of meroplankton abundance were found in the frontal zones, supporting the hypothesis.

Variance partitioning highlighted that the variation in meroplankton abundances was mainly explained by the combined effect of the geographical space and the environmental conditions. In fact, it has been shown that the interaction between the hydrological environment and spatial structure plays a major role on the distribution of meroplankton, especially in estuaries and coastal areas (Ayata et al., 2011; Brandão et al., 2015), meaning that the environmental conditions alone could have a negligible effect, and that larvae are often trapped by hydrological structures and fronts (Shanks et al., 2002).

Regarding the meroplankton community composition, certain groups occurred in association with determined types of frontal systems. Most coastal fronts, coincident with highest surface concentrations of chlorophyll- $a$, were dominated by decapod, cirripede, 
471

472

473

474

475

476

477

478

479

480

481

482

483

484

485

486

487

488

489

490

491

492

493

494

495

496

497

498

499

500

501

502

503

gastropod and bivalve larvae. Previous studies focusing on the benthic megafauna community showed that decapods (mainly crabs Portunus spinicarpus and Hepatus pudibundus) and gastropods (mainly Buccinanops gradatum) dominate the upwelling region off Cape Frio during spring (Léo and Pires-Vanin, 2006). In addition, in the CSTF region and from Babitonga Bay (T7) to CSM (T10) the highest phytoplanktonic densities were observed in the coastal stations, among which, diatoms were the dominant (Becker et al., 2018; Brandini et al., 2014; Moser et al., 2014). In addition, smaller size plankton fractions, including microzooplankton, were found in high abundances associated with coastal processes in Babitonga Bay and CSM sections during the same cruises of the present study (Becker et al., 2018). These resources constitute the main prey items on the diet of bivalve veligers, cirripede nauplii and early crab zoeae (Raby et al., 1994; Turner et al., 2001; Sulkin and McKeen, 1999). Accordingly, gastropods were the most abundant larvae found in a transect in front of Cape Frio area, with higher values at coastal stations (Yoshinaga et al., 2010).

The estuarine front of Patos Lagoon section was dominated by larvae of polychaetes. An association between polychaete larvae and estuarine plumes has been reported in other nearshore environments, mainly associated with the adult species habitats (e.g. Shanks et al., 2002; Ayata et al., 2011). In fact, inside the Patos Lagoon, polychaetes that live on sediments in unvegetated shoals constitute one of the main food resources for birds, juvenile decapod crustaceans, and fishes (Bemvenuti, 1997).

The observed patterns of invertebrate larvae distribution are also very likely to be influenced by the benthic megafauna community, which are the source for the meroplankton community. In fact, we observed consistencies between the distributions of larvae and the benthic community, based on the literature. Larvae of cephalopods showed an association with the offshore waters. The squid Illex argentinus, the cephalopod mostly captured and one of the main deep-sea demersal fishing resources in Brazil and Argentina, presents its highest densities in the shelf break area, where this species is known to spawn (Rossi-Wongtschowski et al., 2006; Vidal et al., 2010).

A biodiversity survey of the benthic community in the continental shelf and slope of the South Brazil Shelf also found that Gastropoda, Bivalvia, Polychaeta, Crustacea and Ophiuroidea were among the most abundant and frequent taxa (Amaral and RossiWongtschowski, 2004). Higher abundances of organisms were associated with sandy and muddy substrata, both mainly present in the shelf until the $200 \mathrm{~m}$ bathymetry (Amaral and 


\section{Conclusions}

The findings of relationships between hydrological structures and invertebrate larvae communities along the South Brazil Shelf add to the accumulating evidence that the frontal systems play an important role in the plankton community, and consequently in the benthic community (Acha et al., 2015). The coast-ocean gradient is a pervasive feature shaping the distribution of the meroplankton community, influenced by several aspects, including distance to the coast and chlorophyll- $a$ concentration. In addition, coastal areas with highly stochastic processes, such as frontal systems, due to the confluence of oceanographic processes of contrasting origin, promote enrichment of the biological productivity. The results support the hypothesis that an increase in meroplankton abundance is observed in the frontal systems present during the spring/summer in the South Brazil Shelf, such as in the Subtropical Shelf Front, in surface thermal and saline fronts, and in the estuarine front derived from the Río de la Plata and Patos Lagoon estuarine front. In addition, the highest concentrations of larvae coincided with the strongest upwelling event present in the studied period, reinforcing the importance of the SACW intrusions to enhance biological production in the coastal euphotic zones (Moser et al., 2014). Different communities of larvae were observed in association with waters derived from the Río de la Plata and Patos Lagoon estuarine front, the oceanic waters, and the coastal waters, indicating the influence of the oceanographic regime in the composition of the meroplanktonic assemblages. The fronts in the South Brazil Shelf perform a fundamental role in enriching nutrients at the euphotic zone, thus fertilizing the generally oligotrophic waters. Here it is shown that a change is also triggered in the plankton community of invertebrate larvae, which responds with an increased abundance in relation to its surrounding areas. Fronts play an important role in phytoplankton production and carbon export. The carbon biomass produced in fronts may be exported downwards, fueling deeper pelagic and benthic communities, which represents an important pathway in the global carbon cycle (Brandini et al., 2018). In addition, frontal systems in a generally oligotrophic shelf, as the South Brazil Shelf, are of paramount importance for sustaining and influencing the length of the food webs (Acha et al., 2015), and thus, for providing ecosystem services (Martinetto et al., 2020). Therefore, a more precise understanding of the effect of frontal systems on integrated ecosystems community is pivotal, and should also be investigated in the light of possible climate change effects.

\section{Acknowledgments}


539 This research was funded by The Brazilian Council for Science and Technological 540 Development (CNPq) and the Brazilian Ministry of Science and Technology (MCT). M.C.

541 Brandão received a $\mathrm{PhD}$ scholarship from the Coordination for the Improvement of Higher 542 Education Personnel (CAPES). A.S. Freire benefited from CNPq grants (312644/2013-2 and 543 311994/2016-4). The authors thank the Brazilian Navy and all crew from the R. V. Cruzeiro 544 do Sul for their logistical support during fieldwork, the researches that helped conducting the 545 field work and analysis in the laboratory, and A. Ciotti and R. Pollery, who provided chlorophyll- $a$ and nutrient data, respectively.

\section{References}

Acha E.M., Mianzan H.W., Guerrero R.A., Favero M., Bava J. (2004) Marine fronts at the continental shelves of austral South America physical and ecological Processes. Journal of Marine Systems, 44, 83-105.

Acha E.M., Piola A., Iribarne O., Mianzan E. (2015) Ecological Processes at Marine Fronts: Oases in the Ocean. Springer, Cham, 68 pp. Ichthyoplankton associated to the frontal regions of the Southwestern Atlantic. In: Hoffmeyer M., Sabatini M.E., Brandini F., Calliari D., Santinelli N.H. (Eds.) Plankton Ecology of the Southwestern Atlantic, From Subtropical to the Subantarctic Realm. Springer, Berlin, pp. 219-244.

Acha E.M., Viñasa M.D., Derisio C., Alemany D., Piola A.R. (2020) Large-scale geographic patterns of pelagic copepods in the southwestern South Atlantic. Journal of Marine Systems, 204, 103281. Brasil - Plataforma Externa e Talude Superior. Instituto Oceanográfico - USP, São Paulo, 216 pp.

Aminot A., Chaussepied, M. (1983) Manuel des analyses chimiques en milieu marin. Centre national pour l'exploitation des océans, Brest, 395 pp. Anderson L.A., Robinson A.R. (2001) Physical and biological modeling in the Gulf Stream region Part II. Physical and biological processes. Deep-Sea Research I, 48, 1139-1168. 
Bakun A. (2006) Fronts and eddies as key structures in the habitat of marine fish larvae: opportunity, adaptive response and competitive advantage. Scientia Marina, 70, 105-122.

Becker E.C., Garcia C.A.E., Freire A.S. (2018) Mesozooplankton distribution, especially copepods, according to water masses dynamics in the upper layer of the Southwestern Atlantic shelf $\left(26^{\circ} \mathrm{S}\right.$ to $\left.29^{\circ} \mathrm{S}\right)$. Continental Shelf Research, 166, 10-21.

Belgrano A., Legendre P., Dewarumez J., Frontier S. (1995) Spatial structure and ecological variations of meroplankton on the French-Belgian coast of the North Sea. Marine Ecology Progress Series, 128, 43-50.

Bemvenuti C.E. (1997) Unvegetated intertidal flats and subtidal bottoms. In: Seeliger U., Odebrecht C., Castello J.P. (Eds.) Subtropical Convergence environments: The coast and the sea in the warm temperate southwestern Atlantic. Springer, New York, pp. 78-82.

Berrick S.W., Leptoukh G., Farley J.D., Rui H. (2009) Giovanni: a web service workflow-based data visualization and analysis system. IEEE Transactions on Geoscience and Remote Sensing, 47, 106-113.

Boltovskoy D. (1981) Atlas del Atlantico Sudoccidental y métodos de trabajo con el zooplancton marino. INIDEP, Mar del Plata, 964 pp.

Borcard D., Legendre P., Drapeau P. (1992) Partialling out the Spatial Component of Ecological Variation. Ecology, 73, 1045-1055.

Borcard D., Legendre P., Avois-Jacquet C., Tuomisto H. (2004) Dissecting the spatial structure of ecological data at multiple scales. Ecology, 85, 1826-1832.

Brandão M.C., Garcia C.A.E., Freire A.S. (2015) Large-scale spatial variability of decapod and stomatopod larvae along the South Brazil Shelf. Continental Shelf Research, 107, 11-23.

Brandini F.P. (2006) Zooplankton and ichthyoplankton distribution on the southern Brazilian shelf: an overview. Scientia Marina, 70, 189-202.

Brandini F.P., Nogueira Jr. M., Simião M., Codina J.C.U., Noernberg M.A. (2014) Deep chlorophyll maximum and plankton community response to oceanic bottom intrusions on the continental shelf in the South Brazilian Bight. Continental Shelf Research, 89, 61-75.

Brandini F.P., Tura P.M., Santos Pedro P.G.M. (2018) Ecosystem responses to biogeochemical fronts in the South Brazil Bight. Progress in Oceanography, 164, 52-62. 
616 Burrage D., Wesson J., Martinez C., Pérez T., Möller Jr. O., Piola A. (2008) Patos Lagoon outflow within the 617 Río de la Plata plume using an airborne salinity mapper: Observing an embedded plume. Continental Shelf 618 Research, 28, 1625-1638.

Campos P.C., Möller Jr. O.O., Piola A.R., Palma E.D. (2013) Seasonal variability and coastal upwelling near Cape Santa Marta (Brazil). Journal of Geophysical Research, 118, 1-14.

622

Castro B.M., Miranda L.B. (1998) Physical oceanography of Western Atlantic continental shelf located between $4^{\circ} \mathrm{N}$ and $34^{\circ}$ S. In: Robinson A.R., Brink K.H. (Eds.) The Sea. John Wiley and Sons, New York, pp. 209-251.

Chaigneau A., Morrow R. (2002) Surface temperature and salinity variations between Tasmania and Antarctica, 1993-1999. Journal of Geophysical Research, 107, 1-8.

628 of mesoscale eddies in Japanese eel larvae dispersal in the western North Pacific Ocean. Scientific Reports, 8 , 5013.

632

Ciotti A.M., Odebrecht C., Fillmann G., Möller Jr. O.O. (1995) Freshwater outflow and Subtropical

634 Convergence influence on phytoplankton biomass on the Southern Brazilian continental shelf. Continental Shelf Research, 15, 1737-1756.

636

Cowen R.K., Lwiza K.M., Sponaugle S., Paris, C.B., Olson D.B. (2000) Connectivity of marine populations: open or closed? Science, 287, 857-859.

639

640 Flint M.V., Sukhanova I.N., Kopylov A.I., Poyarkov S.G., Whitledge T.E. (2002) Plankton distribution associated with frontal zones in the vicinity of the Pribilof Islands. Deep-Sea Research II, 49, 6069-6093.

642

643 Fontes M.L.S., Berri A., Carvalho M., Fonseca A.L.O., Antônio R.V., Freire A.S. (2018) Bacterioplankton 644 abundance and biomass stimulated by water masses intrusions over the Southern Brazilian Shelf (between $645 \quad 25^{\circ} 57^{\prime} \mathrm{S}$ and $\left.29^{\circ} 24^{\prime} \mathrm{S}\right)$. Continental Shelf Research, 164, 28-36.

647 Gaeta S.A., Brandini F.P. (2006) Produção primária do fitoplâncton na região entre Cabo de São Tomé (RJ) e o 648 Chuí (RS). In: Rossi-Wongschowski C.L.D.B., Madureira L.S. (Eds.) O Ambiente Oceanográfico da Plataforma 649 Continental e do Talude na Região Sudeste-Sul do Brasil. EDUSP, São Paulo. pp. 219-264.

651 Heiberger R.M. (2013) HH: Statistical Analysis and Data Display. R package version 2.3-37. Available: http://CRAN.R-project.org/package=HH. Accessed 2015 Aug 31. 
654 Heileman S., Gasalla M.A. (2008) South Brazil Shelf LME - Chapter XVI. In: Sherman K., Hempel G. (Eds). 655 The UNEP Large Marine Ecosystems Report: A Perspective on Changing Conditions in LMEs of the World's 656 Regional Seas. United Nations Environment Programme, Nairobi, 723-734.

657

658 Hidalgo M., Reglero P., Álvarez-Berastegui D., Torres A.P., Álvarez I., Rodriguez J.M., Carbonell A., Zaragoza

659 N., Tor A., Goñi R., Mallol S., Balbín R., Alemany F. (2014) Hydrographic and biological components of the 660 seascape structure the meroplankton community in a frontal system. Marine Ecology Progress Series, 505, 6566180.

662

663 Ito R.G., Garcia C.A.E, Tavano V.M. (2016) Net sea-air $\mathrm{CO}_{2}$ fluxes and modelled $\mathrm{pCO}_{2}$ in the southwestern 664 subtropical Atlantic continental shelf during spring 2010 and summer 2011. Continental Shelf Research, 119, 665 68-84.

666 Joyce T.M. (1983) Varieties of ocean fronts. In: Stern M.E., Mellor F.K. (Eds.) Baroclinic instability and ocean fronts. Woods Hole Oceanographic Institution, Woods Hole, pp. 59.

669

670 Landeira J.M., Lozano-Soldevilla F., Hernández-León S., Barton E.D. (2009) Horizontal distribution of invertebrate larvae around the oceanic island of Gran Canaria: the effect of mesoscale variability. Scientia Marina, 73, 757-767.

673

674

Largier J.L. (2003) Considerations in estimating larval dispersal distances from oceanographic data. Ecological 676 Applications, 13, 71-89. Legendre P., Gallagher E. (2001) Ecologically meaningful transformations for ordination of species data. Oecologia, 129, 271-280.

682 Léo F.C.D., Pires-Vanin A.M.S. (2006) Benthic megafauna communities under the influence of the South

683 Atlantic Central Water intrusion onto the Brazilian SE shelf: A comparison between an upwelling and a non684 upwelling ecosystem. Journal of Marine Systems, 60, 268-284 thermal front in the SW South Atlantic: space/time variability and sea surface temperatures. Continental Shelf

688 Research, 29, 2061-2068.

690 Macedo-Soares L.C.P., Garcia C.A.E., Freire A.S., Muelbert J.H. (2014) Large-scale ichthyoplankton and water 691 mass distribution along the South Brazil Shelf. Plos One, 9, e91241. 
693 Mackas D., Tsurumi M., Galbraith M., Yelland D. (2005) Zooplankton distribution and dynamics in a North 694 Pacific Eddy of coastal origin: II. Mechanisms of eddy colonization by and retention of offshore species. Deep

695 Sea Research II, 52, 1011-1035.

696

697 Marra J., Houghton R.W., Garside, C. (1990) Phytoplankton growth at the shelf-break front in the Middle

698 Atlantic Bight. Journal of Marine Research, 48, 851-868.

699

700 Martinetto P., Alemany D., Botto F., Mastrángelo M., Falabella V., Acha E.M., Antón G., Bianchi A.,

701 Campagna C., Cañete G. et al. (2020) Linking the scientific knowledge on marine frontal systems with

702 ecosystem services. Ambio 49, 541-556.

703

704

Meerhoff E., Tapia F.J., Castro L.R. (2014) Spatial structure of the meroplankton community along a Patagonian 705 fjord - The role of changing freshwater inputs. Progress in Oceanography, 129, 125-135.

706

707

Metzler P.M., Gilbert P.M., Gaeta S.A., Lublan J.M. (1997) New and regenerated production in South Atlantic off Brazil. Deep Sea Research I, 44, 363-384.

709

710

Miranda L.B. (1985) Forma de correlação TS de massas d'água das regiões costeira e oceânica entre o Cabo de São Tomé (RJ) e a Ilha de São Sebastião (SP), Brasil. Boletim do Instituto Oceanográfico da USP, 33, $105-119$.

Möller Jr. O.O., Piola A.R., Freitas A.C., Campos E.J.D. (2008) The effects of river discharge and seasonal winds on the shelf off southeastern South America. Continental Shelf Research, 28, 1607-1624.

Morgan S. (2014) Behaviorally mediated larval transport in upwelling systems. Advances in Oceanography, R.C.G. (2014) Phytoplankton spatial distribution on the Continental Shelf off Rio de Janeiro, from Paraíba do Sul River to Cabo Frio. Hydrobiologia, 728, 1-21.

Muelbert J.H., Acha M., Mianzan H., Guerrero R., Reta R., Braga E.S., Garcia V.M.T., Berasategui A., Gomez724 Erachef M., Ramírez F. (2008) Biological, physical and chemical properties at the Subtropical Shelf Front Zone in the SW Atlantic Continental Shelf. Continental Shelf Research, 28, 1662-1673. concentrated in the highly productive areas of a shelf break front. Marine Ecology Progress Series, 125, 21-30. 
Nybakken J.W. (1997) Marine Biology: An Ecological Approach. Addison Wesley Longman, Menlo Park, 481 pp. matter responses to a deep-water frontal system in the southern California Current System. Journal of Plankton Research, 34, 815-827.

Oksanen J., Blanchet F.G., Kindt R., Legendre P., Minchin P.R., O'Hara R.B., Simpson G.L., Solymos P., Stevens M.H.H., Wagner H. (2013) Vegan: Community Ecology Package. R package version 2.0-7. Available: http://CRAN.R-project.org/package=vegan. Accessed 2015 Aug 31.

Piola A.R., Campos E.J.D., Möller Jr. O.O., Charo M., Martinez C. (2000) Subtropical Shelf Front off eastern South America. Journal of Geophysical Research, 105, 6565-6578.

R Core Team (2018). R: A language and environment for statistical computing. R Foundation for Statistical Computing, Vienna, Austria. https://www.R-project.org/

Raby D., Lagadeuc Y., Dodson J.J., Mingelbier M. (1994) Relationship between feeding and vertical distribution of bivalve in stratified and mixed waters. Marine Ecology Progress Series, 103, 275-284.

Rossi-Wongtschowski C.L.D.B., Ávila-da-Silva A.O., Cergole M.C. (2006) Análise das Principais Pescarias Comerciais da Região Sudeste-Sul do Brasil: Dinâmica Populacional das Espécies em Explotação - II. Instituto Oceanográfico - USP, São Paulo, 96 pp

Schlitzer R. (2009) Ocean Data View, htt://odv.awi.de.

Shanks A.L., Largier J., Brink L. (2002) Observations on the distribution of meroplankton during a downwelling event and associated intrusion of the Chesapeake Bay estuarine plume. Journal of Plankton Research, 24, 391416.

Smith D.L. (1977) A Guide to Marine Coastal Plankton and Invertebrate Larvae. Kendall/Hunt Publishing Company, California, $221 \mathrm{pp}$.

Strickland J.D., Parsons T.R. (1972) A practical handbook of seawater analysis. Fisheries Research Board of Canada, Ottawa, $310 \mathrm{pp}$.

Sulkin S.D., McKeen G.L. (1999) The significance of feeding history on the value of heterotrophic microzooplankton as prey for larval crabs. Marine Ecology Progress Series, 186, 219-225. 
772 Thatje S., Schnack-Schiel S., Arntz W.E. (2003) Developmental trade-offs in Subantarctic meroplankton 773 communities and the enigma of low decapod diversity in high southern latitudes. Marine Ecology Progress

774 Series, 260, 195-207.

775

Turner J.T., Levinsen H., Nielsen T.G., Hansen B.W. (2001) Zooplankton feeding ecology: grazing on phytoplankton and predation on protozoans by copepod and barnacle nauplii in Disko Bay, West Greenland. Marine Ecology Progress Series, 221, 209-219.

Vidal E.A.G., Haimovici M., Hackbart V.C.S. (2010) Distribution of paralarvae and small juvenile cephalopods in relation to primary production in an upwelling area off southern Brazil. ICES Journal of Marine Science, 67, $782 \quad 1346-1352$.

783

784 Villar E., Farrant G.K., Follows M., Garczarek L., Speich S., Audic S., Bittner L., Blanke B., Brum J.R., Brunet C. et al. (2015) Environmental characteristics of Agulhas rings affect interocean plankton transport. Science, 348, $1261447-1261447$. (2010) Vertical distribution of benthic invertebrate larvae during an upwelling event along a transect off the tropical Brazilian continental margin, Journal of Marine Systems, 79, 124-133. 


\section{Tables}

811

812 Table 1. Mean abundance, relative abundance (RA) and frequency of occurrence (FO) of the 813 meroplanktonic larvae sampled along the South Brazil Shelf.

\begin{tabular}{|c|c|c|c|c|}
\hline Phylum/Subphylum & Taxa & Mean (larvae/100 m³) & RA (\%) & FO (\%) \\
\hline Porifera & Porifera & 0.02 & $<0.01$ & 1 \\
\hline Cnidaria & Cnidaria & 2.26 & 0.17 & 17 \\
\hline Platyhelminthes & Platyhelminthes & 2.90 & 0.21 & 17 \\
\hline Nemertea & Nemertea & 4.80 & 0.35 & 8 \\
\hline Annelida & Polychaeta & 243.68 & 17.99 & 69 \\
\hline \multirow[t]{3}{*}{ Mollusca } & Gastropoda & 422.49 & 31.18 & 78 \\
\hline & Bivalvia & 212.30 & 15.67 & 61 \\
\hline & Cephalopoda & 1.92 & 0.14 & 21 \\
\hline \multirow[t]{3}{*}{ Arthropoda/Crustacea } & Cirripedia & 59.40 & 4.38 & 36 \\
\hline & Stomatopoda & 11.91 & 0.88 & 55 \\
\hline & Decapoda & 197.65 & 14.59 & 96 \\
\hline Sipuncula & Sipuncula & 3.58 & 0.26 & 9 \\
\hline Phoronida & Phoronida & 2.02 & 0.15 & 9 \\
\hline \multirow[t]{4}{*}{ Echinodermata } & Ophiuroidea & 49.19 & 3.63 & 16 \\
\hline & Asteroidea & 6.77 & 0.50 & 28 \\
\hline & Holothuroidea & 51.95 & 3.83 & 13 \\
\hline & Echinoidea & 6.83 & 0.50 & 11 \\
\hline Hemichordata & Enteropneusta & 31.31 & 2.31 & 11 \\
\hline- & Trocophores & 13.61 & 1.00 & 28 \\
\hline \multirow[t]{2}{*}{-} & Unidentified & 30.26 & 2.23 & 48 \\
\hline & TOTAL & $1,354.86$ & 100.00 & \\
\hline
\end{tabular}


815 Table 2. Types of fronts intersected over the South Brazil Shelf during late spring 2010 and

816 early summer 2011, response in the abundance of meroplankton (increase in relation to values

817 surrounding stations), and dominant taxa found. STSF = Subtropical Shelf Front. Front types

818 were classified according to Acha et al., 2004 and Acha et al., 2015.

\begin{tabular}{llcl}
\hline Transect & Front type & $\begin{array}{c}\text { Meroplankton } \\
(\sim \text { fold higher })\end{array}$ & Dominant groups \\
\hline T1 - Cape São Tomé & Small-scale & 3 & Decapoda / Gastropoda \\
T2 - Feia Lagoon 2 & Small-scale & - & Gastropoda \\
T3 - Campos Bight & Eddie & 4 & Decapoda / Polychaeta \\
T4 - Cape Frio 1 & Coastal & 5 & Decapoda / Polychaeta \\
T5 - Cape Frio 4 & Coastal & 3 & Decapoda \\
T6 - Ilhabela Island & Coastal & 10 & Gastropoda \\
T7 - Babitonga Bay & Estuarine & 10 & Decapoda / Bivalvia / Gastropoda \\
T8 - Itajaí River & Small-scale & 2 & Decapoda / Gastropoda \\
T9 - Santa Catarina Island & Coastal & 8 & Bivalvia / Ophiuroidea \\
T10 - Cape Santa Marta & Upwelling & 20 & Bivalvia / Gastropoda / Polychaeta \\
T11 - Tramandaí & Coastal & 5 & Ophiuroidea \\
T12 - Mostardas & Small-scale & 3 & Decapoda / Gastropoda \\
T13 - Patos Lagoon & Estuarine & 14 & Polychaeta / Cirripedia / Ophiuroidea \\
& Plume & 10 & Gastropoda \\
T14 - Chuí & STSF & 60 & Polychaeta / Gastropoda \\
& Eddie & 20 & Gastropoda \\
& & &
\end{tabular}

